\title{
Reading the Areopagus Speech in Acts 17 from the Perspective of Sacral Manumission of Slaves in Ancient Greece ${ }^{1}$
}

Andries G. van Aarde

andries.vanaarde@up.ac.za

Professor Emeritus, Department of New Testament Studies,

Faculty of Theology, University of Pretoria

Postal address:

Private Bag X20, Hatfield 0028, Pretoria, South Africa

Tel.: +27 124203806

\begin{abstract}
The article suggests that the metaphor of Paul as seed-picker who gathers dirt from the market in Athens (Acts 17:18) is part of the broad slave metaphor found in Greco-Roman literature and in the New Testament. The stigma of depersonalization, desocialization, and religious marginalization is attached to enslavement. Slaves are excluded from authentic persoonhood. The article explores the rhetoric in Paul's Areopagus speech. It demonstrates Pauline influence on the narrative in Luke-Acts. The essence of the Areopagus speech is the universal unity of humanity and the life-giving effect of the resurrection belief. Building on the notions of fictive kinship and quasi-kinship the article compares the practice of sacral manumission for slaves with that of manumissio in ecclesia.
\end{abstract}

Key terms: Luke-Acts; Paul's kerygma; social death and spiritual life; slavery in antiquity; resurrection belief; fictive kinship

\footnotetext{
${ }^{1}$ This essay is dedicated to Dietmar Neufeld (1949-2015), research associate and friend - never to forget Diet and Viola together with other "Contexters" in the Kruger National Park during a time of recuperation in 2001.
} 


\section{Ad Destinatum Persequor and Tuum Est}

This article commemorates my friendship with the Canadian Dietmar Neufeld who died 9 September 2015. It is an essay about hope for people stifled by social death, as it was for those chained by enslavement in antiquity and until today. Dietmar and I shared the zeal to contribute to life and a hopeful future for all in the faith community. $\mathrm{He}$, located in Vancouver in Canada, and I in Pretoria in South Africa. He who worked at the University of British Columbia for most of his career and I at the University of Pretoria. The motto of his university is Tuum Est, in English, "It is yours" or "It is up to you". The motto of my alma is Ad Destinatum Persequor, translated as "With zeal and perseverance I strive to reach the goal". I cannot think of two better mottos to express Paul's vision, aesthetically narrated by Luke in the Areopagus speech in Acts 17. My proposed theory is that the essence of this speech consists of two motifs: the unity of humankind and immortality, also for slaves - but the challenge is that "it is up to you" to "strive with perseverance to reach the goal".

According to ancient demographical evidence, an inordinately large number of slaves populated the Roman provinces in the East and Western Mediterranean. This was the context of the early Christ-followers. Slaves were recruited in various ways. Some were captured in war. Others were unable to pay their debts and ended up in slavery. A third possibility was children who were born from slave parents. For the Roman military to be operational large grain plantations and herds of cattle had to be maintained. The only way to manage this was to increase slave labor. The mass enslavement of 150,000 people recruited from seventy conquered cities, endorsed by the Roman Senate in 167 B.C.E. provides a glimpse of this reality (Westermann 1955, 29). According to Galen (129-c. 200 or 216 C.E.), the Greek physician, author, and philosopher (see Nutton 2016), his hometown Pergamum in Asia Minor had an adult slave population of forty thousand in the latter part of the second century C.E. According to Westermann's $(1955,87)$ calculation it would mean "one slave to every three adults of the citizen class" (cf. Beavis 1992, 38). Ironically, however, for the Comte de Champagny (1863; in Westermann 1955, 152), "it was the slave system and pagan immortality which, in their combination, ruined the health of the Roman Empire. Only the flame of Christianity could bring to completion a progress which the Christian faith could inspire." For the early Jesus movement, from its its inception, to be faithful to Jesus meant to make a "choice between exclusive membership" or 
"open access to all" (Ferrero 2008, 73-87). The strength and growth of the Jesus movement could also be attributed to its ability "to create itself as an institution because cultural 'talking', its own and others, had prepared a subject ready for its call - a subject that apprehended itself as sufferer" (Perkins 1995, 9). By doing so, "suffering in all its horror is transformed into a treasure and sufferers are honoured" (Perkins 1995, 206).

This essay proposes a theory that aims, along with the many other theories, to explain the enigma of the rapid growth of Jesus-followers as "messianists"during the first four centuries after the execution of Jesus by the Romans. My suggestion is that

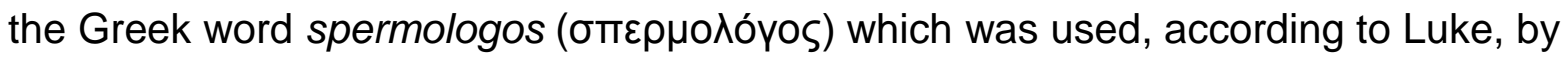
the philosophers in Acts 17:18 to disgrace Paul, probably refers to the apostle "picking up" slaves from the agora in Athens to give them manumissio in ecclesia. Typical of a Hellenistic setting, such as Athens, the agora as market place was linked to temple cult activities. The agora was always filled with slaves and this was also where slaves were traded. The Greek philosopher, geographer and historian Strabo (64/63 B.C.E.- C.E 24) captures how the "spatiality" of the agora was linked with the presence of slaves (Isaac Casaubon 1587, 668): "Merchant, sail in, unload. Everything has been sold" (Strabo 14.5.2). Westermann $(1955,37)$ puts it this way:

In conformity with the general development of trade facilities which characterized the Hellenistic period, the concentration of different marketing activities at different points in the agorai of the Greek trading cities would rationally assign special places in them for the slave sales; but so far as known there were no separate slave markets in the sense in which the term was used in the days of North American slavery.

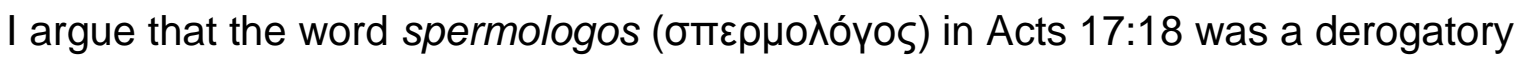
catchphrase used by the philosophers in response to Paul's speech in Athens. It was meant to belittle him. It should be translated as "seed-picker" rather than as "babbler". By implication it refers to a rook that pecks away the rubbish among the cobble stones on the market place. The "rubbish" would most probably refer to the marginalized people who were attracted by Paul's message. My proposal is that the 
"rubbish" alludes to slaves in particular. The appeal of Paul's message probably lay in the idea of immortality gained by symbolic participation by Christ-followers in Jesus' humiliating death, his resurrection and return to where God is/the gods are. That participation in this "rite of passage" was also available to them, the slaves, must have been astounding - that immortality was not only the privilege of philosophers, the nobility, the emperor and his favorites, but also theirs.

For the purpose of this article I will not discuss the difference between the concepts "immortality" and "resurrection". I argue that the resurrection belief was empowering to those who suffered. Through sacral manumission, slaves could experience a transition from social death to spiritual life. For Jesus-followers this meant adoption into God's family. It is a matter of "re-personalization and re-socialization" (Kamen $2012,189)$. The personal reflection on death and rebirth in this article serves as my remembrance of Dietmar's spiritual contribution to my life at a time when early retirement due to ill health and a divorce clouded with intimate family trauma, left me in despair. The breach was healed and gap left by the loss of career was filled with research and publishing work. There was life after death.

The article discusses slavery as social death and the practice of sacral manumission. The argument then moves to the Areopagus speech in Acts 17, subdivided into (i) a semantic and semiological explanation of the Greek term

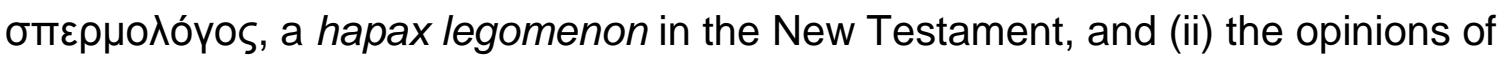
commentators, and (iii) the contextualization of the speech in Luke-Acts by considering the unity of the narrative. In the following section I suggest that LukeActs should be read as a paradigmatic narration on early Christian martyrdom. In the last two sections I propose reading the Areopagus speech in a Stoic context, to explain my theory that the essence of the speech is the unity of humankind and immortality, of also slaves.

\section{Slavery as Social Death and the Practice of Sacral Manumission}

Initially the Jesus movement grew slowly. From the perspective of the Romans (see Cameron 1991, 22 note 26), what Christ-followers practised was superstition (Tacitus, Annales 15:44) or a cult (Lucian, Peregrinus 11) whereas others regarded them as followers of a philosophical system (Celsus, in Origen's Contra Celsum 
6.34). From the end of the first century and for the next 300 years, there was a rapid increased in the growth of the Jesus movement, to the extent that early Christfollowers succeeded in unifying persecutors and the persecuted, emperor and subjects, into a worldwide political power. According to Theodore $(2016,8)$ "the Roman Empire underwent a wholesale political, cultural and social transformation, starting with the reforms of Diocletian and the adoption of Christianity as the official and eventually exclusive religion of the Empire." Many theories in existing literature explain this seeming impossibility (see MacMullen 1984, 1-23). How is it possible that Jesus the Galilean who was crucified by Pontius Pilate (prefect of the Roman province Judaea from AD 26-36 under Emperor Tiberius) as a troublemaker, inspired a movement that permeated the mighty Roman empire and radically transformed it over a period of only 200 years. The enigma is even greater if one takes into account that, for the greater part of these 300 years of rapid growth, the brutal persecution of the followers of "Chrestus" (Suetonius, Claudius 25) mirrored the brutality with which Jesus was killed. This article suggests that slave experience in that context is a significant metaphor for understanding the dynamics and ultimate size of this movement. Orlando Patterson $(1982,70)$ says: "It is generally accepted that Christianity found many of its earliest converts among the slave populations of the Roman Empire, although the fact is surprisingly difficult to authenticate. What is certain, however, is that slave experience was a major source of the metaphors that informed the symbolic structure of Christianity."

The initial followers of Jesus were "messianists". They referred to Jesus of Galilee as

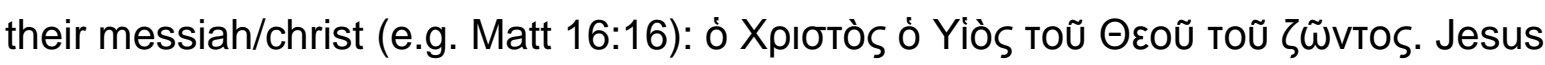
never explicitly referred to himself in these terms. These Christ-followers venerated him with the deifying title of son of God and referred to his vision and mission as "good tidings" similar to that of the Emperor Augustus (e.g. in Mark 1:1): Tò

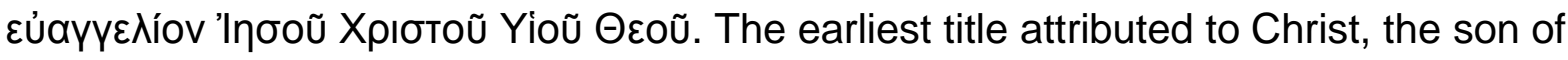
God, was that of Kyrios (1 Th 1:1): Kúpıos 'Inooũ Xрıбтòs. By giving him this name they elevated him to the same level of honor that was bestowed upon the Emperor. All of this contributes to the enigma. My question is: will the slave experience metaphor contribute to a better understanding the enigma? 
Jesus himself said that his followers should not aspire to being like those with political power (e.g. Mark 10:42). They should rather see themselves as slaves because then they would embody his mission and vision (Mark 10:45): kaì ôs ầ

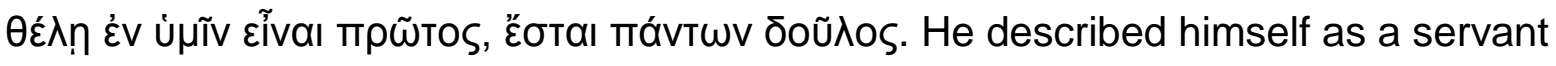
(סıákovos) in the service of all people. He cared most for the marginalized of the world. He healed their trauma by serving them. About a decade and a half after Jesus had spoken these words, the author of Luke-Acts narrates that Jesus, son of God, was not only born through divine intervention (Luke 1:35), but that Mary his mother accepted the divine call and described herself as a slave of the most high

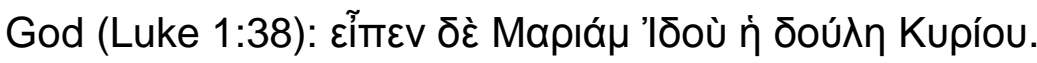

In some ways Luke was influenced by Paul. This can be seen, for example, in the "disapproval of the central slogan of the Roman imperial propaganda, pax et securitas (peace and security)", the notion of a "Spirit-guided church" and that "rich believers donated their wealth to the benefit of the poor" (Kim 2008, 6; 148). Paul is probably the most influential early Christian author and the one who gave the Jesus movement its greatest momentum. Paul, as a free male Roman citizen, was willing

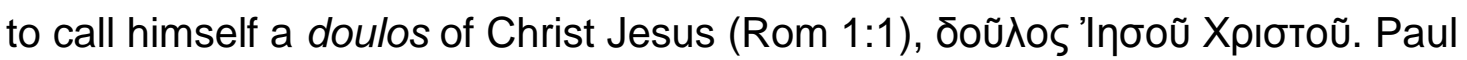
explains the divine event of Jesus becoming one with the human condition by means of the metaphor of slave experience. Similar to Luke, Paul ascribes Jesus' divine origin as that Jesus shares in the sphere of the divine (Phil 2:6): "Christ Jesus has

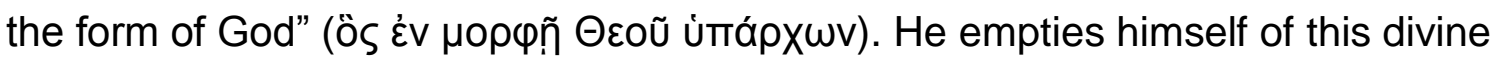
honor and accepts the human condition (ensarkikos) in the form of a humiliated

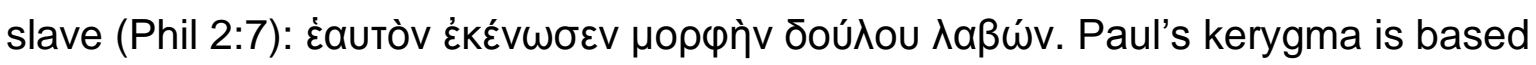
on the humiliation of the crucifixion and also of the exaltation of the humiliated slave to one who is higher than emperors.

According to Paul, those who unashamedly associate with and are loyal to Jesus will be victorious despite their human condition. He calls it a "living by faith" (Rom 1:17):

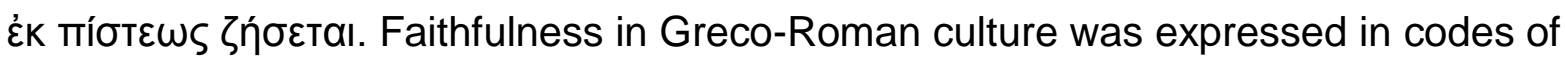
honour-shame and patron-client (see Crook 2004, 167-177). The term "loyalty" is therefore a better equivalent for words from the míris-root than "faith". It refers to a mind-set of "fidelity". Paul's notion "faith alone" refers to "undivided loyalty" (see Van Aarde 2017; to be published). The gospel that Paul proclaims without shame is the 
power of God through which both Judean and Greek find salvation (Rom 1:16).

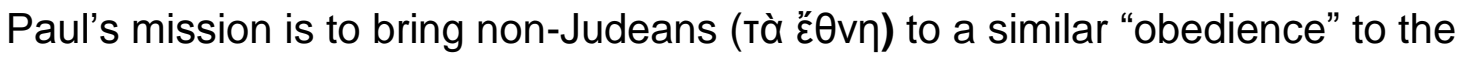
values of this faithfulness (míotıS). The ingroup of Christ-followers and the outgroup

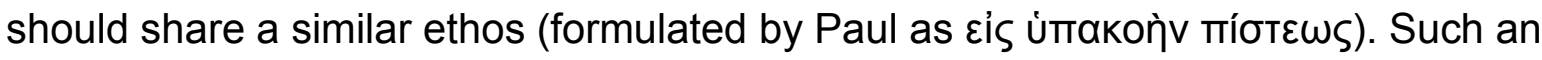
ethos includes the eradication of enmity, alienation and socio-cultural boundaries

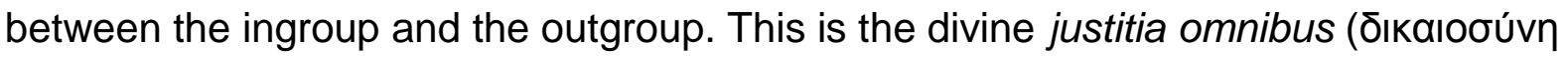

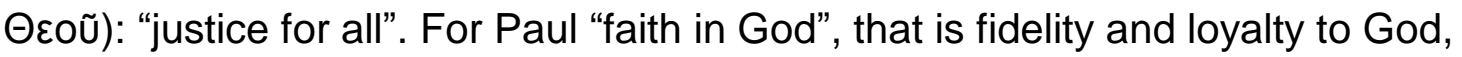
means trust in God as Totenerwecker (the one who resurrects the dead) (Hahn [2002] 2005, 268) - that is the one who resurrects those who are enslaved to social death. Here, in Romans 4:24, "faith" is trusting in God who resurrected Jesus from

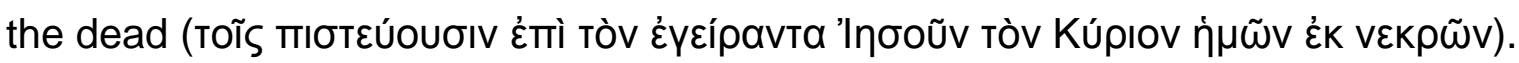

In Paul's kerygma the slave experience of Jesus and the exaltation of slaves are connected with the crucifixion of Jesus. The power of the Spirit of God freed him from the despair of the human condition so that he could participate in the divine household. Such participation entails a renewal of mind (Rom 12:2). Christ Jesus and his followers are the examples of such an obedience to the will of God. In cultic language: though baptism one dies with Christ and is resurrected with Christ (Rom $6: 4)$. Both the cross and the resurrection are core elements of this slave experience metaphor. Paul says he is speaking "in human terms" (Rom 6:16-19a): "Do you not know that if you yield yourselves to any one as a obedient slaves, you are slaves of the one whom you obey, either of sin, which leads to death, or of obedience which leads to righteousness? But thanks to God, that you who were once slaves of sin

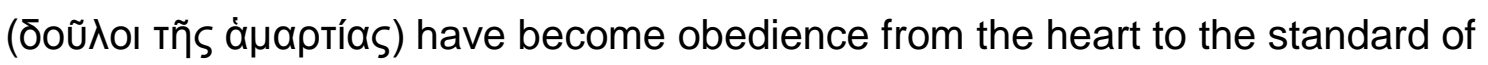
teaching to which you were committed, and, having been set free from sin, have

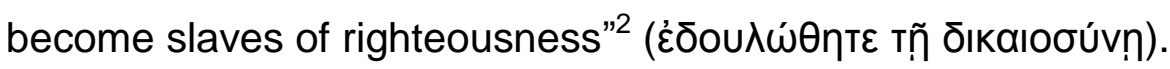

Decades later, toward the end of the first century, the Gospel of John expresses a similar idea. The author also traces the origin of the man of Galilee to a divine enactment (Jh 1:1-14). For Bultmann $(1971,65)$ it means that the ^óyos became human in this (historical) man from Galilee (cf. Labron 2011, 27). This person -

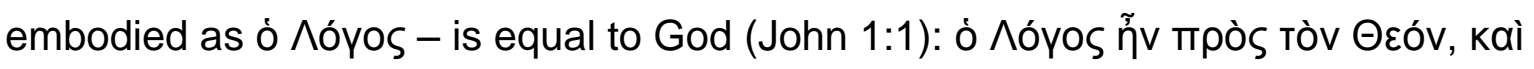

\footnotetext{
${ }^{2}$ Revised Standard Version, in Aland and Aland (1992, 419).
} 


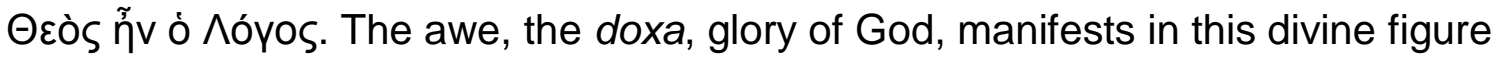
(John 1:14) who became part of the human condition (ensarkikos): kaì ò ^óyo $\sigma a ̀ p \xi$

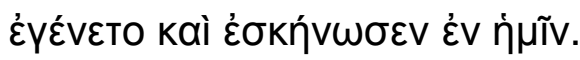

This transition from one condition to another, where the first condition has not come to an end, but simultaneously the second condition gives meaning to life by displacing despair with hope, is explained in the literature of the early Christfollowers by means of the concept "fictive kinship". Orlando Patterson $(1982,65)$, in his study of the slave metaphor, calls this "quasi-filial kinship". In my interpretation of the Pauline and Lukan use of the expression "becoming part of the faith community in Christ", I apply this concept to slaves becoming part of and belonging to the faith community. I refer to it as manumissio in ecclesia, an expression known from the time of Constantine (e.g., Codex lustinianus: Liber I, 1.13, recognovit Paulus Krueger 1906), although analogous to Hellenistic and Judaic practice (Westermann 1955, 130). However, contra fellow-South African, classist Chris de Wet (2008, 1-13), I do not see it as a legal practice that "helped [Christians] to cultivate a generally negative attitude towards slavery." It should rather be interpreted in terms of the concept "quasi-filial kinship". While people are part of real biological kinship relations, the fictive kinship also becomes real. In the Greco-Roman context this paradoxical existence in two types of kinship simultaneously made a profound difference to the quality of life of slaves.

The slave experience metaphor in Pauline theology enunciates something similar. In a private letter to the master of a slave in Colossae, Philemon, Paul asks the master to not react according to custom, which would be to brutally punish the runaway slave, but rather to change the quality of the life of the slave who has returned. Philemon should see Onesimus as more than a slave. He should regard him as a brother. In this way Onesimus becomes part of a community of Christ-followers that constitutes a quasi-filial kinship. Paul applies this to his own relationship with the runaway slave Onesimus whom he encountered in jail. Fictive kinship became a reality between the free person, Paul, and the runaway slave, Onesimus, because the slave became "like a child" to Paul. However, Paul is not his fictive "father" in a hierarchically biological sense. Both the free person and the slave become "children of God", in other words constituting a quasi-filial kinship. 
On this theme the Pauline letter to the Romans elaborates. In his last letter Paul uses two metaphors to compares the two types of kinship (Rom 8:15). The one is

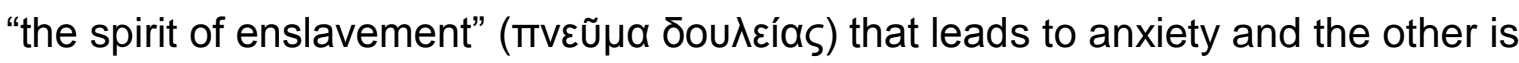

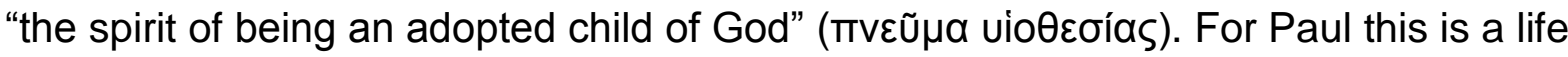
ruled simultaneously by both the human condition (kata sarka) and the spirit of God (kata pneuma). Although your "body is dead" your "spirit is alive" (Rom 8:10). To partake of the divine while still being fully in the human condition, requires a metamorphosis: to become the embodiment of the disposition of Christ Jesus which is obedience to the will of God (Rom 12:2). Paul also connects this with participation in the crucifixion of Jesus on the one hand and the resurrection of Jesus on the other. Because the same "spirit" that brought Christ from social death to spiritual life also fires up the Christ follower (Rom 8:11), the slave can also be child of God.

This quasi-filial kinship and participation in the resurrection of Jesus Christ can also be found in tales of the early martyrs among the Christ followers. The life of the young woman Febronia is an example (see Brock and Harvey 1987, 150-176). The tale, ostensibly written in the sixth century C.E., refers back to the time of Diocletian at the end of the third century C.E. According to legend, Febronia was part of a faith community of women that formed a fictive kinship, though some of them were also biological kin. The abbess of the women's monastery, Bryaena, was for example also the biological aunt of Febronia. This real kinship relationship is not negated in the story (Workman [1923] 2014, 196). At the beginning of the fourth century at height of the persecution of Christians, emperor Diocletian in C.E. 284-305 commanded that Christians in Assyria also be persecuted. The young woman, Frobonia's fictive faith community lived in Nisibis. She refused to be disloyal to her community in Christ to become the sexual property of one of the perpetrators. She described herself as a slave of Christ as well as the bride of Christ. She was tortured terribly while the invitation remained throughout: if she changed her mind, she would be freed. She refused and was set alight, her hands severed, and she was decapitated. This legend of martyrdom demonstrates how the slave metaphor empowered followers of Christ through the first three centuries of the early Jesus movement. It enacts the kerygma of carrying the cross as Jesus did. 
According to J. Gordon Davies (1976, 120), the core elements of Pauline theology can be explained by elements from slave experience, for example redemption, justification and reconciliation. Redemption is the act of setting a slave free (cf. Schnelle 2003, 494). This means nothing more than just moving from one human

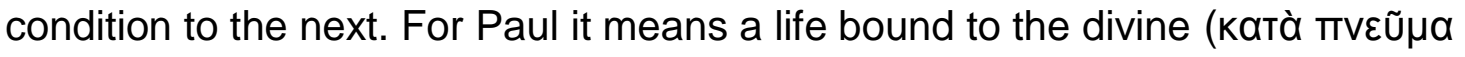

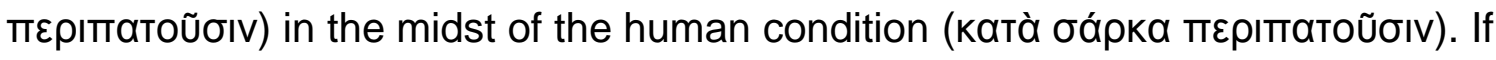
justification is understood as absolution (cf. Byrne 1996, 21), the verdict will "not guilty". For Paul the righteousness of God means that the chains of the human condition are broken. It is as though the enslavement never happened (Davies 1976, 120). Justification does not only have a juridical connotation. It is also expression of right relationship (see Louw \& Nida 1988, 452-453). Both these connotations can be seen in the letter to the Romans (Hahn 2006a, 271-297; [1998] 2006b, 305-308).

In the worldview of antiquity, life in the human condition is not regarded as separate from the world of the gods. What happens in the one world is influenced by the other. The disturbance of economic and political stability by Christ-followers led to intensified persecution. Christ-followers could no longer participate in the religious cult that kept the Pax Romana upright (cf. Castelli 2004, 57; 101). Tacitus (Annales I.41), was the first who used the term Pax Augusta and Seneca (De Clementia I.4.1) the first who referred to it as the Pax Romana. Publius Aelius Aristides (Oration 26) called this "peace" a matter of the gods (cf. Behr 1968, 88-89; Wengst [1986] 1987, 9 note $14 ; 173$ note 15$)$. The gods ruled the cosmos and the Emperor the earth. He was not only ruler but also the "father", the benefactor of his political kingdom and the whole world. On the other hand the gods were the redeemers and protectors of the Empire (Wengst [1986] 1987, 47). They demanded from the Emperor to be the steward of the gifts - peace, security and prosperity - that they bestowed upon his political kingdom (cf. Carter 2001, 24). Roman emperors therefore employed religious rites to legitimate their political power and actions. The temple and the agora were the religious spaces where the subordinates in the Roman provinces had to present their produce from the land on scheduled religio-political festival days according to the imperial calendar (cf. Woolf 2012). At the agora and the temples, mediated by priests, the taxes paid by the populus (e.g. agricultural sacrifices) kept the balance between the reign of the political powers and that of the divine powers 
(cf. Petit 1967, 74). The religious rituals represented a mystification of the imperial edicts aimed at political sustainability (cf. Carter 2001, 20). The cult of rites was recognition of the gods and expression of obedience to them. It also expressed their gratitude for the security they had in life, because the gods protected the cosmos (cf. Shelton 1988, 70-71).

Every land conquered by the Romans took part in maintaining this economic and political stability (Petit 1967, 74). Initially some "Christian" slave-owners tried to avoid their cultic obligations by delegating it to their slaves. This had not only economic consequences, but also had political and religious relevance. When the slaves became members of the community in Christ, they too refused. A large scale refusal to participate in the cult would lead to a collapse of the market. The Empire was threatened by enemies from the outside and economic and the political instability from the inside. Both were attributed to the dissatisfaction of the gods and the Christfollowers were blamed for it.

However, from the perspective of a hermeneutics of suspicion, "Christian" slaveowners need not only be seen as the victims of the powers that be. Jennifer Glancy (2003) argues that the "Christian discourse" encoded cultural anxiety with the slave metaphor and attests to an uncritical acceptance of the ethical patterns of a slaveholder morality. She acknowledges that in both "pagan" and "Christian" communities in the Greco-Roman context the faithfulness of slaves were rewarded by being given a higher rank and a more honorable position, which increased their social influence. However, Augustan slave reform (Kleijwegt 2016) only made formal manumission possible for slaves above the age of thirty. A reward of greater trust was not the same as manumission. Greater trust only led to greater responsibility, which meant that being a slave became even more difficult (cf. Beavis 2003, 117). Glancy's argument has it merits, but should be refined. Manumissio in ecclesia should not be anachronistically understood as what we know from present-day civil rights movements.

The dialectic between the symbolic universe and the social universe in antiquity creates a very particular context in which the slave experience metaphor in the literature of early Christ-followers should to be understood. Orlando Patterson (1982, 
38) asks: "If the slave no longer belonged to a community, if [s] he had no social existence outside of his [her] master, then what was [s]he?" The answer is: desocialized, depersonalized; that is a kind of social death. The slave "can never be brought to life again as such since, in spite of some specious examples ... of fictive rebirth, the slave will remain forever an unborn being" (Patterson 1982, 38). When they were sold to another master they became slaves in a different household. Even when they were legally set free, they were never truly free. The stigma of having once been a slave, remained. The only absolute freedom possible for a slave was "sacral manumission". However, it is because of the weakness of such a "nobodiness" that the power (mana) of the divine creates a gateway for being transformed from a "nobody" into a "somebody". Patterson $(1982,51)$ articulates such a transition of "impassable boundaries" as follows:

The essence of slavery is that the slave, in his social death, lives on the margin between community and chaos, life and death, the sacred and the secular. Already dead, he lives outside the mana of the gods and can cross the boundaries with social and supernatural impunity.

Against this background, the slaves and ex-slaves played and extraordinary role in the emperor cult. Emperor worship became popular "at street level" (cf. Hopkins 1978, 197-242; Patterson 1982, 69). In the Roman cults a slave could acquire freedom if gods, such as Apollo, Sarapis or Asklepios, became their new owner. However, it did not mean that emperor worship was accepted by all. For slaves sacral manumission became important "for the simple reason that the emperor's cult introduces into Roman law the alien principle of asylum for slaves" (Patterson 1982, 69). Yet the "dominating emotion behind worship" was still fear, because of the despotic "earthly power" of their owner. There is "no trace of sacred manumission" in Athens. Patterson puts it as follows:

The idea of finding freedom in servitude to a god remained alien to Greek thought. The slave who was sold to Apollo was not given freedom by the god; he merely acquired a de facto freedom by virtue of the fact that the god did not exercise his 
proprietary powers. This was a net way of solving the problem created by the naturalistic theory of slavery. If the slave was by nature fit for nothing else, how could he become free? If he was socially dead, how could he be made socially alive? It was not possible (Patterson 1982, 67-68).

This does not mean that sacral manumission did not occur in ancient Greece. Deborak Kamen $(2012,174-194)$ points out that evidence of sacral manumission is found "all over the Greek world ... from the archaic period to the Roman era, with the bulk from the Hellenistic period." The difference with the Roman emperor cult lay in the fact that sacral manumission in Greece did not presuppose an "absolute freedom". It rather implied a "fictive consecration to a god" and a "fictive sale to a god" - most commonly to Sarapis or Asklepios (Kamen 2012, 177). Over a thousand inscriptions from the temple of Apollo at Delphi show that more than 1,350 slaves were freed between 201 B.C.E and 100 C.E. (Kamen 2012, 80).

In all these incidences Apollo or Asklepios became the slave's new owner as if the slave were the possession of the god. The expression "as if" ( $\dot{\omega} \varsigma \mu \grave{)})$ in the sentence is crucial. In another essay where I discussed examples of the usage of "anti-society language" (Van Aarde 2014), I pointed out the rich use of "as if" in both Paul's and Epictetus' Stoic way of speaking. For example, in I Corinthians 7, Paul discusses marital kinship as both "real" and "fictive" and he contextualized it in the ancient

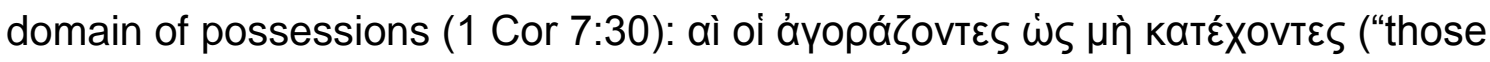
who buy as though they had not goods". To me, this example of simultaneously belonging and not belonging - being simultaneously possessed and not - is similar to the position of a slave after sacral manumission. The Pauline phrase in Galatians 3:26-28 attests to the same ambiguity and quasi-filial kinship: "in Christ Jesus you are all sons of God ... there is neither Jew nor Greek; there is neither slave nor free; there is neither male nor female; for you are all one in Christ Jesus" (Revised Standard Version, in Aland and Aland 1992, 498). In that essay I elaborated on the ambiguous "as if" relationship in terms of the "divine economy", in the Stoic sense (Van Aarde 2014, p. 9 of 10): 
The implicature ... of the "divine economy" is to "live as if not ['als ob nicht' - Vollenweider 2013:149) you die' (in Greek, ws

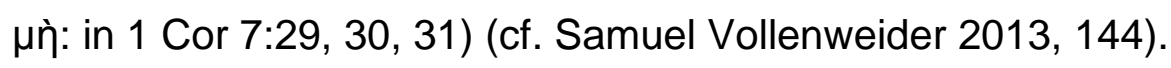
The pragmatic dimension of this [Stoic] diaphorical assertible ... consists of a life-giving transformative interactional event: the displacement of the "authentic" with the "authentic other", being aware of otherness by applying the law of love as the ground rule in the divine economy of the basileia - irrespective of whether in marriage or in management, according to both Paul and Epictetus (Balch 1983, 429); female and male are "similar" and each other's equal (Balch 1983, 439), the same for being a slave, or a "lame old man", or an exposed child. This radical love was, is and remains the essence of the divine economy of the basileia.

After sacral manumission, what was the benefit to the slave, aside from the god becomes the slave's helper and protector? The Roman author Aelian (On the Nature of Animals 10.49) says that Apollo is not only a savior, he is also the father of the healer god Asklepios who had the power to bring dead men back to life (cf. Aeschylus, Agamemnon 1022-3) (Kamen 2012, 186). Kamen (2012, 188-189), in her reference to the cross-cultural anthropological work of Orlando Patterson (1982), says that such "notion should not necessarily surprise us: a conception of slavery as (social) death is found in almost all slave-holding societies".

However, I contend that, on this point, Kamen $(2012,189)$ misunderstands Patterson's $(1982,211)$ intention, as though he argued that sacral manumission implied "life-giving" and "life-creating" (in the sense of "repersonalization and resocialization") in real kinship terms. The freedom slaves gained does not pertain to "real kinship" but only to fictive kinship and quasi-filial kinship. Yet, surprisingly, in her concluding remarks Kamen $(2012,190)$ acknowledges Patterson's insight that the slave "was never completely healed' or 'reborn", and "did not become a citizen", but instead "occupied an intermediate status somewhere between slave and citizen ... lacking many important rights and privileges" (see also Zelnick- 
Abramovitz's 2005 book, Not Wholly Free; esp. ch. 6). Freedom in the Roman sense of asylum is not to be found in Athens (Patterson $(1982,67)$.

To explain the paradox of being liberated as if ( $\dot{\omega} \varsigma \mu \grave{)}$ ) absolutely free, but not in reality, Patterson $(1982,67)$ speaks of "rites of reversal". He concurs with the South-African born anthropologist Max Gluckman (1962; 1970) who, in his fieldwork among Southern African indigenous tribes, learnt that enacting role reversal is culturally forbidden. He calls it "rituals of rebellion". Normally it expresses disagreement with the powers that be. Such "ritualized forms of hostility", similar to anti-society language, oppose existing tradition, norms and practices. An example would be that peasants take the place of kings. This is not an ongoing "revolution". It rather creates equilibrium, social cohesion and is beneficial to the social order.

In reality if someone became a slave [s] he has lost all the privileges of free people and was completely marginalized with the status of a non-person. This status could never be turned around, which means that such a person could never really be free. They would always retain the stigma. Being set free from slavery by means of sacral manumission improved a slave's social position to some extent. Absolute freedom was only possible if someone were to become the property of neither human beings nor gods. Another kind of role reversal should to take place if someone were to be considered equal to any other person and, without stigma, become a member of the unity of all humankind. Only then the person be absolutely free. My suggestion is that the concept of reversal, in the ambiguous sense of the word, inspired large numbers of slaves to become part of the faith community of Christ-followers. That would mean that to become a slave of Christ would be to be freed from all human beings and their gods. This can be illustrated by means of Paul's Areopagus speech in Acts 17. It understandable that the resurrection faith would be attractive to slaves. It assumes a transformation of the human condition. It emphasizes a transition from rubbish, rubble, non-personhood to personhood and child of God status.

\section{The Areopagus Speech in Acts $\mathbf{1 7}$}

I am convinced that the second section of the Luke-Acts sequence, known as the Acts of the Apostles, originated in the early second century C.E. (see Pervo 2006) 
unlike the Gospel of Luke which was probably from 80-90. I agree with Schmithals $(1982,13)$ that Acts shows a pre-Marcion tendency - in other words its origin should be before 120-125 C.E. (cf. Tyson 2006). The author and readers should therefore have been aware of the increasing influence of the Roman emperor cult. Acts, as a political apology, indicates that the author, a Jesus-follower, does not see the movement as a threat to the emperor cult. However, the author and the readers of Acts could in no way escape or ignore the effects of the emperor cult. Both his political apology against the Roman emperor cult and "Luke's" pre-Marcion tendencies show that the historical Paul had an influence on his life. What the relationship between the author and Paul was, is not known to us. The Papias tradition of the early church that the author was the "Luke" who had travelled with Paul, cannot be defended historically (cf. Wolter 1997, 405-426). The author was clearly well informed regarding Paul's life, from the time of his conversion until the end of his life in Rome. The content of Paul's letters to the Thessalonians, First Corinthians and Romans bears a strong resemblance to the way in which Paul is portrayed in Acts. Paul's references to his visits to Philippi, Thessaloniki, Beroea, Athens and Corinth show notable similarities with the narratives about these visits in Acts. Though Paul's Areopagus speech in Acts 17 is clearly a Lucan creation, the themes in the speech resonate with Pauline theology, especially themes from his letters to the Philippians, First Corinthians, the letter to Philemon and Romans. Today it is generally accepted that First Thessalonians and Romans - respectively Paul's first and last letters - were written in Corinth.

There are different facets to the Pauline influence on the author of Luke-Acts against the background of pre-Marcion tendencies. Two are relevant to this essay, namely Paul's description of himself as "slave of Christ" and, secondly, that his kerygma of the crucifixion and resurrection of Jesus can be explained by means of themes from the Hebrew Scriptures and that the central meaning of this kerygma is imbedded in "die jüdische Erwartung der Totenauferstehung" (the "house of Israel's" expectation of the resurrection of the dead) (Schmithals 1982, 9). From both these perspectives - the Jesus-follower as slave of Christ and the Jesus-follower as member of a fictive faith community which originated because of the death and resurrection of Jesus - it becomes clear that Luke-Acts is a sequence narrative. Tuckett $(1999,164)$ describes this "unity" as follows: "Jesus is the Messiah figure of 
Jewish expectation, fulfilling all messianic expectations albeit in a highly unusual and distinctive way, i.e. via his exaltation to God's right hand in heaven, where his 'true' throne is to be located." Loveday Alexander $(1999,436)$ elaborates on this:

[I]t is not difficult to read Luke-Acts as a diptych for which the Ascension narrative provides the hinge: before it becomes the Gospel, predominantly devoted to Jesus; after it comes Acts, predominantly devoted to the apostles. This focus on the person of the proclaimer and the act of the proclamation itself is, as we have seen, accentuated in the ending of Acts, where their overt focus on the text is very much the person of Paul (vv. 17-22) and on the Gospel message itself as its reception (vv. 23-31).

If Luke is read as a "paradigmatic" narration (סıńүnбıৎ - Luke 1:1) early Christian martyrdom comes to the fore (cf. Moessner 1986, 220-256). In such a narration the protagonist (and the apostles as his helpers) is a role model (exemplum / paradigma) for the readers. Schmithals $(1982,9)$ formulates it as follows: "The suffering of Jesus does not have any fundamental salvific meaning. It is an example of martyrdom to fulfil Hebrew Scripture (the suffering servant of God) and shows the continuity between Israel and the acts of Jesus" (my translation and paraphrase from the German).

For the purposes of this essay I will not elaborate further on the sequel of Jesus, Peter, Paul and the figure "Loukas", which assists in the understanding of the narrative of martyrdom in Luke-Acts and its reception. Nevertheless, I want to emphasize that Luke-Acts should be seen as a circle composition. Peter and Paul as "slaves" proclaim the reign of God and the Lord Jesus Christ is portrayed as God's "holy servant". The proclamation is expressed with boldness and fully unhindered

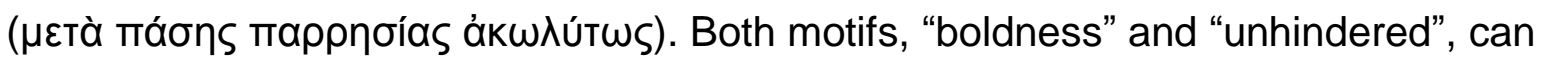
be found at the beginning of the narrative (Acts 4:29, 31) and at the end (Acts 28:31). If it is seen as a narrative of martyrdom, it can be interpreted as "good news for slaves" (Dowling 2011, 123-140). Beacons in the narrative are where the characters are called slaves: Mary (Luke 1:68b), Peter (Luke 12:21, 42, 43; Acts 
4:29), Peter and John (Acts 4:29) and Stephen. Stephen's message was about the liberation from slavery in Egypt (Acts 7:34).

Core motifs in Paul's Areopagus speech are that he, similar to the Stoic disposition, sees humankind as a unity: God placed people in different places on the globe, which constitute the unity of all people in the household of God. Humankind in totality forms the fictive kinship of God's children. The second core element of the speech is Paul's emphasis that the crucified Jesus was resurrected by God from the dead. This means that he was exalted to the godly sphere as God's holy servant. "All people, whether Judean or Greek, man or woman, old or young" (see Acts 2:14-21) is clearly an indication that people of every social status are included: leaders and followers, officers or soldiers, slave owners or slaves.

For slaves, this message of participation in the exalted Christ is equivalent to a sacral manumission. In Greek and Roman manumission the slave was both free and not fee. Participation in Christ is a manumission by which the slave becomes a member of the divine household. This meant absolute freedom, accepted as any other member of the household. However, influenced by Paul, this new kinship remains an "as if" ( $\dot{\omega} \varsigma \mu \grave{)})$. Participation in the resurrection of Christ means freedom, but still in the midst of the human condition.

The reaction of the philosophers to Paul's speech, or as Luke characterizes it in philosophical language, "disputation," is varied (Loisie 2004, 223). ${ }^{3}$ Some respond,

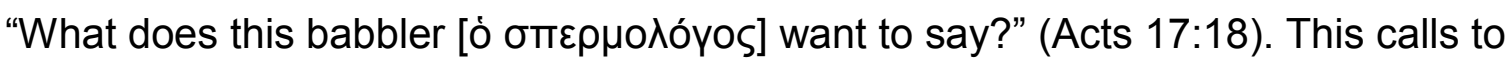
mind a term used by the Stoic philosopher Dio Chrystostom (c. 40-112 C.E.) to dismiss the teaching of the Cynics, who "post themselves at street-corners, in alleyways, and at temple-gates, pass around the hat, and play upon the credulity of lads and sailors and crowds of that sort, stringing together rough jokes and much

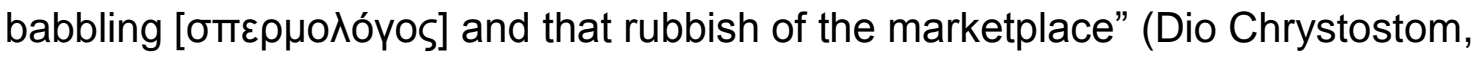
Discourses 32.9, transl. A.J. Malherbe 1989, 15).

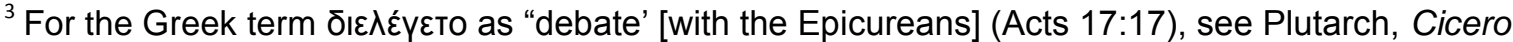
24.5; Diogenes Laertius, Lives of eminent philosophers 2.30, 45, 122). For the Greek term

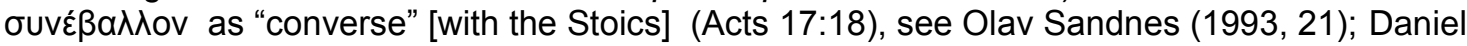
Marguerat 2013, 72; Loisie 2004, 234 note 19).
} 


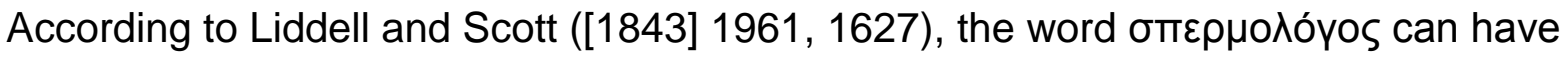
different referential meanings: (i) "picking of seeds, like birds"; as "rook" compared to "guttersnipes"; (ii) picking of scraps, gossiping; (iii) one who picks up and retails scraps of knowledge, an idle babbler, gossip. In the "semantic dictionary" of Louw

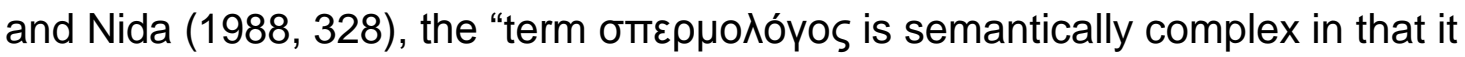
combines two quite distinct phases of activity: (1) the acquiring of information and (2) the passing on of such information. It has a figurative extension of meaning ... based on the practice of birds in picking up seeds." In other words, "one who acquires bits and pieces of relatively extraneous information and proceeds to pass them on with pretence and show - ignorant show-off, charlatan." Louw and Nida $(1988,432)$ also

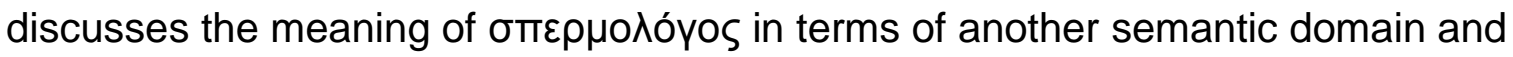
say: "originally a reference to birds picking up seed, but figuratively applied to a person who is an information scavenger ... one who is not able to say anything worthwhile in view of the miscellaneous collection of titbits of information - foolish babbler." Bruce ([1951] 1976, 333) refers to Ramsay $([1915] 2015,96)$ who

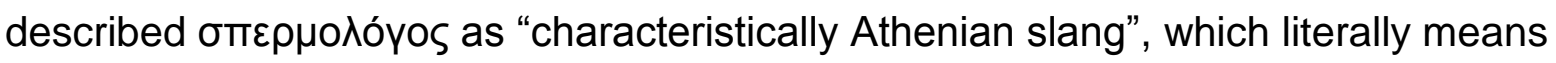
"seed-picker, and as such might be used of a gutter-sparrow that picks up scraps in the market (cf. Long 2004, 102). ${ }^{4}$

Standing in the middle of the Areopagus in Athens (Acts 17:22) - probably thinking of the cosmopolitan crowd gathering together at the agora with its eventful slave trade - Paul the "gutter-sparrow" picking of the scraps among humankind, uses and

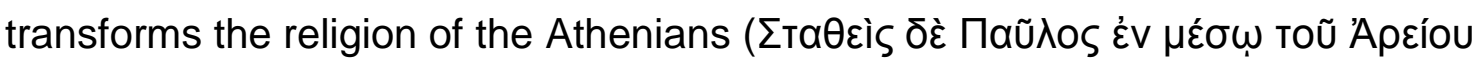

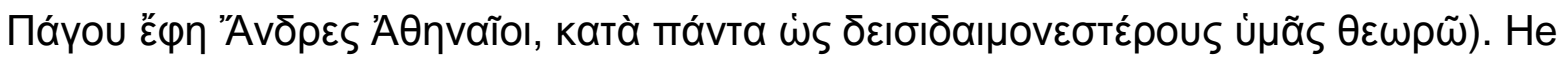
speaks about the "unknown God" (Acts 17:23) who gives life to everyone from everywhere on earth. This is where the Creator God reigns (Acts 17:25-26). Belonging to this God is a totally different kind of belonging to the gods of GrecoRoman tradition who are worshipped in "handmade temples" (Acts 17:28). Belonging

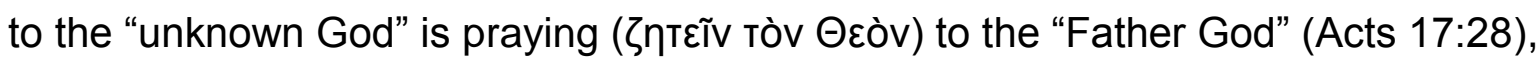
"feeling after" ( $\psi \eta \lambda \alpha \varphi \eta ́ \sigma \varepsilon ı$ av aủtòv) this God (i.e. become conscious of God and of

\footnotetext{
${ }^{4}$ Demosthenes [384-322 B.C.E], in Papyrus Oxyrhynchus 25, a third-century manuscript of De

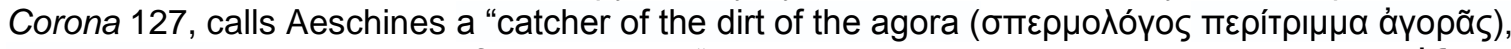

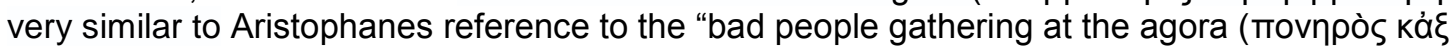
áyopãs) (Long 2004, 102).
} 
their relation to God) and "finding" (عüpoıєv ) this God (Acts 17:27). For we are

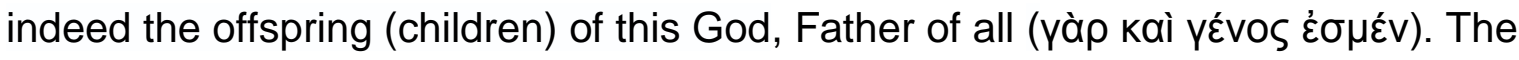

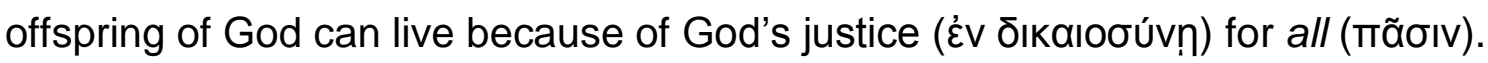
Also slaves are granted the ability to be faithful to a new life because of their transition from social death to spiritual life. This absolute new relationship of "seeking", "feeling", and "finding" is ascertained (Acts 17:31) through God'

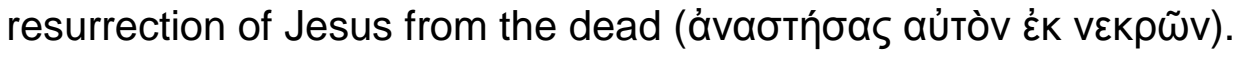

\section{4. "It's Up to You" (Tuum est)}

It seems that the commentators are saying Tuum est; it is up to you. I conclude my argument by bringing this motto of Dietmar Neufeld's alma mater into harmony with my own: Ad destinatum persequor, that is "aiming at my goal". The understanding of sacral manumission as constituting quasi-filial kinship has contributed to our understanding of the metaphor "seed picker" in Acts 17:18. Paul is compared with a rook that picks at the rubbish among the cobble stones of the plaka in the agora, the centre of the slave trade where people are bought and sold, human beings are made non-human, where people are declared rubbish - a stigma they will never lose.

There Paul proclaims this powerful Jesus kerygma. Irrespective of where in the world the slaves (cf. Acts 2:18) came from (cf. Acts 17:26), whatever their sex or age (cf. Acts $2: 17$ ), whatever the size of their debt or their humiliation as soldiers who lost the war, they all became part of the household of God. This was made possible because the nobody who had been crucified by the Romans was also God's holy servant (Acts 4:27). Now the slave is like Paul - and Peter and John. Both are slaves of Christ (cf. Acts 4:29). Together they are children of God. Their human condition will not necessarily change. In their new relationships they will again experience rejection. But, like God's holy servant and the other servants of God, Peter and Paul,

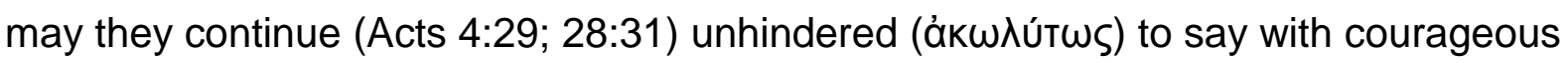

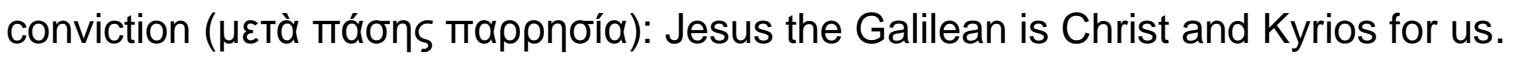

\section{Bibliography}

Aland, Kurt and Barbara Aland 1992. Greek-English New Testament, sixth edition. Stuttgart: Deutsche Bibelgesellschaft. Alexander, Loveday 1999. "Reading Luke-Acts from Back to Front." In J. 
Verheyden (ed.), The Unity of Luke-Acts, pp. 419-446. Leuven: University Press. (Bibliotheca Ephemeridum Theologicarum Lovaniensum CXLII).

Balch, David L. 1983. "1 Cor 7:32-35 and Stoic Debates about Marriage, Anxiety, And Distraction." Journal of Biblical Literature 102(3), 429-439. http://dx.doi. org/10.2307/3261016

Beavis, Mary Ann 1992. "Ancient Slavery as an Interpretative Context for the New Testament Servant Parables with Special Reference to the Unjust Steward (Luke 16:1-8)." Journal of Biblical Literature 111(1): 37-54.

Behr, Charles A. 1968. Aelius Aristides and the Sacred Tales. Amsterdam: Hakkert. Woolf, Greg 2008. "Divinity and Power in Ancient Rome." In N. Brisch (ed), Religion and Power: Divine Kingship in the Ancient World and Beyond. Chicago: The Oriental Institute of the University of Chicago. (Oriental Institute Seminars, 4).

Brock, Sebastian and Susan A. Harvey 1987. Women in the Syriac Tradition. Berkeley: University of California Press.

Bruce, F.F. [1951] 1976. The Acts of the Apostles: The Greek Text with Introduction and Commentary. Leicester: Inter-Varsity Press.

Bultmann, Rudolf 1971. The Gospel of John: A Commentary, transl. G.R. Beasley-Murray; edited by R.W.N. Hoare and J.K. Riches. Philadelphia: Westminster Press.

Byrne, Brendan 1996 Romans. Collegeville: The Liturgical Press. (Sacra Pagina Series vol. 6, A Michael Glazier Book).

Cameron, Averill 1991. Christianity and the Rhetoric of Empire: The Development of Christian Discourse. Berkeley: University of California Press.

Carter, Warren 2001. Matthew and Empire: Initial explorations. Harrisburg: Trinity Press International.

Castelli, Elizabeth A. 2004. Martyrdom and Memory: Early Christian Culture Making. New York: Columbia University Press.

Casaubon, Isaac [1587] 2016. Strabo's Geography, reproduced from Strabonis rerum geographicarum libri IIXV [with] Isaaci Casauboni commentaries et castigations (The 17 books about geographical matters by Strabo, with commentary and notes by Isaac Casaubon). Retrieved 27 October 2016, at www.sl.nsw.gov.au

Comte de Champagny, Franz 1863, Les Antonins - ans de J.C., 69-180. Paris Ambroise Bray. 
Crook, Zeba 2004. "BTB Readers Guide: Loyalty.” Biblical Theology Bulletin: A Journal of Bible and Theology 34: 167-177.

Davies, J. Gordon 1976. Christians, Politics and Violent Revolution. London: SCM Press.

De Wet, Chris, 2008. “John Chrysostom on Slavery.” Studia Historiae Ecclesiasticae 34(2): 1-13.

Dowling; Elizabeth V. 2011. "Luke-Acts: Good News for Slaves?" Pacifica: Australasian Theological Studies 24: 123-140.

Ferrero, Mario 2008. "The Triumph of Christianity in the Roman Empire: An Economic Interpretation." European Journal of Political Economy 24(1): 7387.

Glancy, Jennifer 2003. Slavery in Early Christianity. Oxford: Oxford University Press. Gluckman, Max 1962. Essays on the Ritual of Social Relations. Manchester: Manchester University Press.

Gluckman, Max 1970. "The Utility of the Equilibrium Model in the Study of Social Change." American Anthropologist 72: 21-237.

Hahn, Ferdinand [2002] 2005. Theologie des Neuen Testaments, Band 1. Die Vielfalt des NeuenTestaments: Theologiegeschichte des Urchristentums. 2., durchgesehene und ein Sachregister ergänzte Auflage. Tübingen: Mohr Siebeck.

Hahn, Ferdinand 2006a. "Entwicklung in den Aussagen über die Rechtfertigung, bei Paulus?". In F. Hahn (ed.), Studien zum Neuen Testament, Band II: Bekenntnisbildung und Theologie in urchristlicher Zeit, edited by Jörg Frey, pp. 271-297. Tübingen: Mohr Siebeck. (Wissenschaftliche Untersuchungen zum Neuen Testament, 192).

Hahn, Ferdinand [1998] 2006b. "Gerechtigkeit Gottes und Rechtfertigung des Menschen nach dem Zeugnis des Neuen Testaments,". In F. Hahn (ed.), Studien zum Neuen Testament, Band II: Bekenntnisbildung und Theologie in urchristlicher Zeit, edited by Jörg Frey, pp. 299-312. Tübingen: Mohr Siebeck. (Wissenschaftliche Untersuchungen zum Neuen Testament, 192). Untersuchungen zum Neuen Testament, 192).

Hopkins, Keith 1978. "Divine Emperors, or the Symbolic Unity of the Roman Empire." In K. Hopkins (ed.), Conquerors and Slaves, pp. 197-242. Cambridge: 
Cambridge University Press. (Sociological Studies in Roman History, 1). Kamen, Deborah 2012. "Manumission, Social Rebirth, and Healing Gods in Ancient Greece." In D. Geary and S. Hodkinson (eds.), Slaves and Religions in Graeco-Roman Antiquity and Modern Brazil, pp. 174-194. Newcastle upon Tyne: Cambridge Scholars Publishing.

Kim, Seyoon 2008. Christ and Caesar: The Gospel and the Roman Empire in the

Writings of Paul and Luke. Grand Rapids: Eerdmans Publishing.

Kleijwegt, Marc 2009. "Creating New Citizens: Freed Slaves, the State and

Citizenship in Early Rome and under Augustus." European Review of History:

Revue européenne d'histoire 16(3): 319-330. Retrieved 26 October 2016 at

http://dx.doi.org/10.1080/13507480902916829

Krueger, Paulus 1906. "Codex lustinianus." In Corpus Iusis Civilis Stereotypa

Octava, Volumen Decundum. Berolini: Apud Weidemanos

Labron, Tim 2011. Bultmann unlocked. London: T\&T Clark International.

Liddell, Henry G. and Robert Scott (eds.) [1843] 1961. A Greek-English Lexicon. A new edition revised and augmented H.S. Jones. Oxford: Clarendon Press.

Loisie, Lynn A. 2004. "Paul's Speech on the Areopagus: A Model of Cross-Cultural Evangelism: Acts 17:16-34." In R.L. Callagher \& P. Hertig (eds.), Mission in Acts: Ancient Narratives in Contemporary Context, pp. 221-238. New York: Orbis Books, New York.

Long, Fredrick J. 2004. Ancient Rhetoric and Paul's Apology. Cambridge University Press

Louw, Johannes P. \& Nida, Eugene A. (eds.) 1988. Greek-English Lexicon of the New Testament based on semantic domains, Volume 1: Introduction and domains. New York: United Bible Societies.

MacMullen, Ramsay 1984. Christianizing the Roman Empire, AD 100-400, New Haven: Yale University Press.

Malherbe, Abraham J. 1989. Paul and the Popular Philosophers. Minneapolis: Fortress.

Marguerat, Daniel 2013. Paul in Acts and Paul in his Letters. Tübingen: Mohr Siebeck. (WUNT 310).

Moessner, David P. 1986. “'The Christ Must Suffer': New Light on the Jesus-Peter, Stephen, Paul Parallels in Luke-Acts." Novum Testamentum 28(3): 220-256. Nutton, Vivian 2016. “Galen of Pergamum: Greek Physician.” Retrieved 26 October 
2016 at https://www.britannica.com/biography/Galen-of-Pergamum

Patterson, Orlando 1984. Slavery and Social Death: A Comparative Study.

Cambridge: Harvard University Press.

Perkins, Judith 2012. The Suffering Self: Pain and Narrative Respresentation in the Early Christian Era. London: Routledge.

Pervo, Richard I. 2006. Dating Acts: Between the Evangelists and the Apologists.

Santa Rosa: Polebridge Press.

Petit, Paul 1967. Pax Romana, transl. J. Wills. Berkeley: University of California Press.

Ramsay, William M. [1915] 2015. The Bearing of Recent Discovery on the

Trustworthiness of the New Testament, Classic reprint. London: Hodder and Stoughton.

Sandnes, Olav 1993. "Paul and Socrates: The Aim of Paul's Areopagus Speech." Journal for the Study of the New Testament 50: 12-26.

Schmithals, Walter 1982. Die Apostelgeschicte des Lukas. Zürich: Theologischer Verlag. (Zurcher Bibelkommentare).

Schnelle, Udo 2003. Paulus: Leben und Denken. Berlin: De Gruyter.

Shelton, Jo-Ann 1988. As the Romans Did: A Sourcebook in Roman Social History. Oxford: Oxford University Press.

Theodore, Jonathan 2016. The Modern Cultural Myth of the Decline and Fall of the Roman Empire. London: Palgrave Macmillan.

Tuckett, Christopher M. 1999. "The Christology of Luke-Acts.". In J. Verheyden (ed.), The Unity of Luke-Acts, pp. 133-164. Leuven: University Press.

(Bibliotheca Ephemeridum Theologicarum Lovaniensum CXLII).

Tyson, Joseph B. 2006. Marcion and Luke-Acts: A Defining Struggle. Columbia:

University of South Carolina Press.

Van Aarde, Andries G. 2014. "Pragmatic Dimensions in Parable Research and the Divine Economy of the Basileia". HTS Theological Studies 70(1), Art. \#2688, 11 pages. http://dx.doi. org/10.4102/hts.v70i1.2688

Van Aarde, Andries G. 2017. "'By faith alone' (undivided loyalty) in light of change agency theory: Jesus, Paul, and the Jesus-group in Colossae." HTS

Theological Studies 73(3). To be published.

Verheyden, Joseph 1999. "The Unity of Luke-Acts: What Are We Up To?". In J. 
Verheyden (ed.), The Unity of Luke-Acts, pp. 3-56. Leuven: University Press. (Bibliotheca Ephemeridum Theologicarum Lovaniensum CXLII).

Vollenweider, Samulel 2013. "Lebenskunst als Gottesdienst: Epiktets Theologie und inr Verhältnis zum Neuen Testament.| In S. Vollenweider, M. Baumbach \& E. Ebel (eds.), Epiktet: Was ist wahre Freiheit?: Diatribe IV 1, pp. 119-162.

Tübingen: Mohr Siebeck. (Scripta antiquitatis posterioris ad ethicam religionemque pertinentia, 22).

Wengst, Klaus [1986] 1987. Pax Romana and the Peace of Jesus Christ, transl. J. Bowden. London: S C M Press.

Westermann, William L. 1955. The Slave Systems of Greek and Roman Antiquity. Philadelphia: The American Philosophical Society.

Woolf, Greg 2012. Rome: An Empire's Story. Oxford: Oxford University Press.

Wolter, Michel 1997. "Israels Zukunft und die Parusieverzögerung bei Lukas." In M.

Evang, H. Merklein \& M. Wolter (eds.), Eschatologie und Schöpfung:

Festchrift für E. Grässer, pp. 405-426. Berlin: De Gruyter. (BZNW 89).

Workman, Herbert B. [1923] 2009. Persecution in the Early Church: A Chapter in the History of Renunciation. Eugene: Wipf \& Stock.

Zelnick-Abramovitz, Rachel 2005. Not Wholly Free: The Concept of Manumission and the Status of Manumitted Slaves in the Ancient Greek World. Leiden: Brill. (Mnemosyne Suppl., 266). 